\title{
ANALISIS KESULITAN SISWA DALAM MEMBACA PERMULAAN DI KELAS SATU SEKOLAH DASAR
}

\author{
Inne Marthyanne Pratiwi \\ Vina Anggia Nastitie Ariawan \\ Universitas Pendidikan Indonesia \\ Jln. Setia Budhi No. 229 Bandung 40154 \\ e-mail: sayainne@gmail.com ${ }^{1}$
}

\begin{abstract}
This study is designed to describe the reading difficulties on basic reading within first graders of elementary school. The research used the qualitative approach with case study method. The subject of this study is first graders of elementary school. The data collection were gerenated from observation and interviews. The thematic analysis and the validity of the data were using triangulation and reflexivity. The results showed that the difficulty in basic reading of first graders of elementary school are: (1) inability to identify diphthong, vocal double, and consonant cluster, (2) inability to read a sentence, (3) reading haltingly, (4) inability to mention a few consonants, (5) inability to spell well, (6) reading carelessly, (7) quickly forgeting the word he or she has been spelled, (8) adding and replacing words, (9) long-period of spelling, and (10) inability to read thoroughly.
\end{abstract}

Keywords: trouble, basic reading, elementary school, spell, ideas, elementary school

\begin{abstract}
Abstrak: Penelitian ini bertujuan untuk mendeskripsikan kesulitan membaca permulaan di kelas I SD. Penelitian menggunakan pendekatan kualitatif dengan metode studi kasus. Subjek siswa kelas I. Teknik pengumpulan data observasi dan wawancara. Analisis tematik sedangkan validitas data menggunakan triangulasi dan refleksivitas. Hasil menunjukkan bahwa kesulitan dalam membaca permulaan siswa kelas I SD yaitu: (1) belum mampu membaca diftong, vokal rangkap, dan konsonan rangkap, (2) belum mampu membaca kalimat, (3) membaca tersendatsendat, (4) belum mampu menyebutkan beberapa huruf konsonan, (5) belum bisa mengeja, (6) membaca asal-asalan, (7) cepat lupa kata yang telah diejanya, (8) melakukan penambahan dan penggantian kata, (9) waktu mengeja cukup lama, dan (10) belum mampu membaca dengan tuntas.
\end{abstract}

Kata kunci: kesulitan, membaca permulaan, sekolah dasar, mengeja, gagasan

Kebiasaan membaca permulaan di awal merupakan salah satu cara untuk keterampilan dan kemahiran dalam kemampuan untuk merancang gagasan utama. Curtain, dkk (2016:23) mengungkapkan bahwa keterampilan dalam menuliskan gagasan terkait dengan kemampuan membaca. Untuk itulah, pengembangan gagasan memegang peranan utama dalam proses penggagasan ide. Dalam kajian
Silverman, dkk (2017:118) merupakan pengkajian yang sesuai dengan prinsip kemandirian. Kemampuan untuk keterampilan dan kemandirian dalam berbahasa menjadi strategis. Dalam artian kemampuan tersebut meski dijadikan padanan dalam kemahiran berbahasa di sekolah dasar. Fokus utama adalah kemampuan dalam pengusaan kosa-kata dan penguasaan dasar-dasar kebahasaan. 
Pendapatan Granger (2016:2) mengunakan gagasan yang menyesuakan varisties kebahasaan. Dalam proses pembelajaran bahasa. Hal ini memegang prinsip bahwa keberadaan data-data yang disesuaikan menjadi pemegang kunci dalam proses pembelajaran berbahasa melintas budaya. Pada prinsipnya kemampuan untuk melakukan editing menjadi kemampuan berbahasa. Pendapat dari Schleppegrell (2016:118) merupakan salah satu fungsi dalam kegiatan dalam kegiatan perancangan yang memadai. Dalam artian, penggunaan konten dalam tata bahasa merupakan tujuan dalam pengembangan keterampilan yang sesuai dengan prinsip pembelajaran kebahasaan. Pada prinsipnya, keterampilan untuk berbahasa merupakan kemampuan dalam prinsip keterampilan dan kemahiran berbahasa.

Membaca merupakan kemampuan yang harus dikuasai siswa di sekolah dasar karena kemampuan membaca secara langsung berkaitan dengan seluruh proses belajar siswa (Rahim, 2008). Siswa dikategorikan siap membaca ketika mereka mampu mengidentifikasi atau memahami makna kata dari benda-benda yang disebut oleh orang lain, meskipun siswa belum mampu membunyikan huruf dari nama benda tersebut (Bond, dkk, 1994). Misalnya, ketika guru mengatakan sabun maka siswa dapat menunjukkan sabun. Ketika siswa sudah mampu mengidentifikasi makna kata maka siswa mulai memasuki tahap membaca permulaan.

Pada tingkatan membaca permulaan, pembaca belum memiliki kemampuan membaca sesungguhnya tetapi masih dalam tahap belajar untuk memperoleh kemampuan membaca (Abidin, 2010). Membaca permulaan adalah salah satu aspek keterampilan berbahasa yang berlangsung selama dua tahun untuk jenjang kelas satu dan kelas dua sekolah dasar. Membaca pada tingkat permulaan merupakan kegiatan belajar mengenal bahasa tulis dan siswa dituntut untuk menyuarakan lambang-lambang bunyi bahasa (Zubaidah. 2013). Membaca permulaan di sekolah dasar mencakup (a) pengenalan bentuk huruf; (b) pengenalan unsur linguistik; (c) pengenalan hubungan ejaan dan bunyi (menyuarakan tulisan); dan (d) melancarkan bacaan dalam taraf lambat sebagaimana yang dikaji oleh Tarigan (2008).

Tahap awal membaca permulaan yaitu anak dikenalkan dengan bentuk huruf abjad dari $\mathrm{A} / \mathrm{a}$ sampai dengan $\mathrm{Z} / \mathrm{z}$. Huruf tersebut perlu dilafalkan anak sesuai dengan bunyinya. Setelah anak diperkenalkan dengan bentuk huruf abjad dan melafalkannya langkah selanjutnya anak diperkenalkan dengan mengeja suku kata, membaca kata, dan membaca kalimat pendek berdasarkan pendapat Dalman (2014). Misalnya, kata /kaki/ anak dilatih mengeja suku kata $/ \mathrm{ka} /$ dan $/ \mathrm{ki} /$. Suku kata $/ \mathrm{ka} /$ dieja /ka-a/ ${ }^{\circledR}[\mathrm{ka}]$ dan suku kata /ki/ dieja /ka-i/ ${ }^{\circledR}[\mathrm{ki}]$ lalu dibaca kaki. Selain mengeja dan membaca, membaca permulaan juga menitikberatkan pada penguasaan aspek bersifat teknik yang bertujuan melatih siswa menyuarakan lambang-lambang tulisan dengan tepat, lafal yang baik, serta intonasi yang wajar menurut Rosdiana, dkk (2011).

Pada tahap membaca permulaan, anak diberi bekal untuk mengetahui sistem tulisan, cara mencapai kelancaran membaca, memusatkan kata-kata lepas dalam cerita sederhana, dan belajar mengintegrasikan bunyi dan sistem tulis berdasarkan kajian dari Slavin, dkk (2014). Ketepatan dan keberhasilan pada tahap membaca permulaan akan berdampak besar terhadap peningkatan kemampuan membaca selanjutnya. Dalam proses pembelajaran membaca permulaan siswa sering mengalami kesalahan berdasarkan kajian dari Petersen, et. al (2016) Hal ini dikarenakan siswa kelas permulaan pada umumnya belum dapat membaca tulisan atau lambang bunyi dengan baik. Kesalahan yang terjadi dapat berupa kesalahan mengenali huruf, kata, dan kalimat yang semuanya terlihat dalam bunyi yang diucapkan menurut Zubaidah (2013).

Kesalahan membaca permulaan apabila tidak segera diatasi tentunya akan berdampak pada kemampuan membaca siswa. Siswa yang tidak mampu membaca dengan baik akan mengalami kesulitan dalam mengikuti kegiatan pembelajaran Rahim, (2008). Siswa yang tidak mampu membaca juga akan mengalami kesulitan dalam menangkap dan memahami informasi yang disajikan dalam berbagai buku pelajaran, buku-buku bahan penunjang, dan sumber-sumber belajar tertulis yang lain Abidin (2010). Kesulitan membaca merupakan suatu keadaan individu yang memiliki kemampuan membaca rendah berdasarkan rerata kemampuan membaca yang telah ditetapkan Lyon, et. al (2003) Sementara itu, menurut Snowling (2013) kesulitan membaca merupakan suatu keadaan ketika siswa tidak mampu mengidentifikasi kata sehingga siswa memiliki kecepatan membaca yang lambat dan memiliki pemahaman bacaan yang rendah. 
Bertitiktolak dari penelitian sebelumnya maka peneliti mencoba melakukan penelitian serupa dengan subjek penelitian yang berbeda. Peneliti hendak melakukan penelitian tentang kesulitan siswa dalam membaca permulaan di kelas satu sekolah dasar. Selain itu, penelitian sebelumnya menganalisis kesulitan membaca siswa dalam bahasa Inggris sedangkan peneliti akan menganalisis kesulitan membaca siswa dalam bahasa Indonesia. Analisis kesulitan membaca permulaan di kelas satu sekolah dasar dilakukan mengingat belum ada yang melaksanakan penelitian ini. Oleh sebab itu, peneliti akan mengadakan penelitian dengan tujuan untuk mengeksplorasi atau menemukan kesulitan siswa dalam membaca permulaan di kelas satu sekolah dasar.

\section{METODE}

Jenis penelitian ini adalah penelitian dengan pendekatan kualitatif. Penelitian kualitatif adalah penelitian untuk memahami fenomena tentang apa yang dialami oleh subjek penelitian dengan cara deskripsi dalam bentuk kata-kata dan bahasa berdasarkan hasil pengamatan Margono, (2014). Sementara itu, metode yang digunakan adalah studi kasus. Penelitian studi kasus adalah penelitian dengan menggunakan pendekatan kualitatif dengan tujuan untuk mengeksplorasi kehidupan nyata, sistem terbatas kontemporer (kasus) atau beragam sistem terbatas (berbagai kasus), melalui pengumpulan data secara detail dan mendalam yang melibatkan beragam sumber informasi dan melaporkannya secara deskripsi Creswell, (2015). Dalam penelitian ini, peneliti tidak melakukan tindakan untuk membuktikan suatu strategi atau metode pembelajaran. Namun, peneliti melakukan observasi, wawancara, dan menganalisis dokumen untuk menemukan kesulitan siswa dalam membaca permulaan di kelas satu sekolah dasar.

Penelitian diadakan di salah satu sekolah dasar kecamatan Lembang. Partisipan dari penelitian ini ialah empat siswa kelas 1A dan lima siswa kelas 1B yang memiliki kesulitan membaca atau memiliki masalah dalam membaca. Identifikasi siswa yang memiliki kesulitan membaca didasarkan pada nilai tes membaca siswa yang kurang dari kriteria ketuntasan minimal serta berdasarkan informasi yang diperoleh dari guru kelas. Partisipan lainnya dalam penelitian ini ialah guru kelas $1 \mathrm{~A}$ dan kelas $1 \mathrm{~B}$.
Data dikumpulkan melalui observasi dan wawancara. Observasi adalah proses melihat, mengamati, mencermati, dan merekam perilaku secara sistematis untuk memperoleh data sehingga dapat digunakan untuk memberikan suatu kesimpulan atau diagnosis (Suharsaputra, 2014). Dalam observasi ini, peran peneliti yaitu mengamati dan mencatat/merekam fenomena yang sedang diteliti tanpa berperan sebagai partisipan. Hasil observasi dicatat dalam catatan lapangan.

Wawancara dalam penelitian ini adalah wawancara dengan pertanyaan terbuka (open-ended questions) yang diberikan oleh peneliti kepada partisipan sehingga partisipan dapat menyalurkan pengalamannya dengan sebaik-baiknya tanpa dibatasi oleh perspektif peneliti atau temuan peneliti sebelumnya. Jawaban terbuka (open-ended response) terhadap pertanyaan memungkinkan partisipan untuk menciptakan opsi-opsi untuk merespons (Creswell, 2015).

Dalam menganalisis data, peneliti menggunakan tematik analisis dengan mengadaptasi enam langkah dalam proses analisis dan interpretasi data kualitatif menurut Creswell (2014). Keenam langkah tersebut adalah (1) mempersiapkan, mengorganisasikan data, mentranskrip wawancara, dan mengetik ulang catatan lapangan; (2) coding; (3) menggunakan kode untuk membangun deskripsi dan tema; (4) merepresentasikan temuan dalam tampilan visual; (5) menginterpretasi temuan dengan mengemukakan pandangan pribadi, membuat perbandingan antara temuan dengan kepustakaan, dan menyebutkan keterbatasan; dan (6) memvalidasi keakuratan temuan dengan menerapkan prosedur triangulasi dan refleksivitas.

Validitas data dalam penelitian kuallitatif adalah kegiatan untuk menilai keakuratan suatu temuan yang telah dideskripsikan oleh peneliti berdasarkan hasil pengumpulan data Creswell (2014). Validitas data dalam penelitian ini menggunakan triangulasi dan refleksivitas. Triangulasi merupakan suatu proses pemanfaatan persepsi yang beragam untuk mengklarifikasi makna, memverifikasi kemungkinan pengulangan dari suatu observasi atau interpretasi dengan prinsip tidak ada observasi dan interpretasi yang dapat diulang (Denzin \& Lincoln, 2009). Triangulasi merujuk pada pengumpulan informasi sebanyak mungkin dari berbagai sumber melalui berbagai metode (Cohen, et. al, 2007). Penelitian ini menggunakan triangulasi jenis data yang diperoleh 
dari catatan lapangan dan hasil wawancara. Selain itu, peneliti juga memperoleh data dari sumber yang beragam yaitu guru kelas dan siswa kelas $1 \mathrm{~A}$ dan 1B sekolah dasar.

Refleksivitas mengacu pada kesadaran peneliti dalam memosisikan diri pada tulisannya dimana peneliti sadar akan bias, nilai, dan pengalaman yang dia bawa (Creswell, 2015). Peneliti sangat penting untuk tidak hanya menerangkan pengalamannya dengan fenomena yang sedang diteliti tetapi peneliti juga menyadari bahwa pengalaman ini sangat mungkin memengaruhi temuan, kesimpulan, dan penafsirannya dalam penelitian. Peneliti harus menjaga sikap, menunjukkan persahabatan, dan berusaha tak terlihat di kelas agar pembelajaran berjalan natural atau tidak dibuat-buat. Peneliti tidak berhak ikut campur dan memaksa partisipan untuk melakukan kegiatan yang dikehendaki peneliti.

\section{HASIL DAN PEMBAHASAN}

Peneliti melakukan observasi ketika guru memberi tes membaca pada siswa kelas I khususnya pada siswa yang mengalami kesulitan membaca. Peneliti mencatat kesulitan yang dialami siswa berdasarkan kategori kesulitan membaca yang telah ditentukan. Berikut ini hasil observasi terhadap sembilan siswa yang mengalami kesulitan membaca.

Catatan Lapangan 1. Siswa A sudah mampu membedakan huruf dan melafalkan huruf secara jelas. Siswa A sudah mampu membaca kata terbuka yang terdiri dari dua suku kata. Kesulitan yang dialami siswa A yaitu belum mampu membaca kata yang terdiri dari 3 suku kata. Selain itu, siswa A juga belum mampu membaca diftong serta konsonan dan vokal rangkap. Siswa A hanya bisa membaca kalimat dengan kata yang terdiri dari suku kata terbuka. Kalimat-kalimat lain dibaca Siswa A dengan sembarangan (tidak sesuai/ mengarang).

Catatan Lapangan 2. Siswa B sudah mampu mengeja dengan baik dan lafal yang jelas. Siswa B lancar dalam membaca dua suku kata terbuka. Namun, tersendat-sendat dalam membaca kata yang terdiri dari tiga suku kata dan membaca kata berakhiran vokal-diftong. Siswa B belum bisa membaca kata menjadi satu kalimat. Apabila guru meminta siswa untuk membaca dari awal, ia akan mengulang bacaan dengan cara mengeja".

Catatan Lapangan 3. Siswa C sudah bisa mem- bedakan huruf vokal tetapi tidak mampu menyebutkan beberapa huruf konsonan. Siswa $\mathrm{C}$ belum bisa mengeja sehingga guru memberikan gambar untuk ditebak. Siswa C bisa menyebutkan nama-nama gambar dengan lancar. Hal ini membuktikan bahwa Siswa $\mathrm{C}$ sebenarnya sudah siap untuk belajar membaca akan tetapi waktu yang dibutuhkan tidak secepat teman-teman yang lain.

Catatan Lapangan 4. Siswa D sudah mampu membaca kata serta frasa dengan lancar. Namun, siswa D belum mampu membaca kalimat dengan lancar khususnya kalimat yang tidak ada suku kata terbukanya, seperti "seragam". Ketika siswa D membaca kalimat yang menurutnya sulit tampak siswa D mengerutkan dahi seperti sedang memikirkan perkiraan bacaan yang tepat. Kemudian siswa D membaca kalimat tersebut berdasarkan hasil pemikirannya sendiri.

Catatan Lapangan 5. Siswa E sudah lancar dalam membaca kata dan frasa. Namun, ketika membaca kalimat masih cukup tersendat-sendat dan lupa kata yang telah diejanya terutama kata yang ada di depan kalimat. Penambahan dan penggantian kata juga dilakukan oleh siswa E ketika membaca kalimat. Contohnya, ketika ada kalimat "Bobi membeli buku" menjadi "Bobi membeli baju" atau "Sepatu Dona baru" menjadi "Sepatu punya Dona baru.

Catatan Lapangan 6. Siswa F sudah cukup lancar dalam membaca. Namun, siswa F terlihat sangat terburu-buru ketika membaca. Terutama ketika membaca kalimat. Siswa F seringkali melakukan penggantian atau penambahan kata dalam membaca kalimat. Contohnya, "Bobi membeli buku" menjadi "Bobi membaca buku" atau "Seragam Cika bersih" menjadi "Seragam Cika yang bersih". Konsentrasi siswa F juga mudah teralihkan jika mendengar teman-temannya sedang gaduh.

Catatan Lapangan 7. Siswa G sudah bisa membaca kata meskipun mengeja dengan waktu yang cukup lama. Begitu juga dengan membaca frasa. Hampir semuanya bisa ia baca dengan jelas. Namun, siswa G menolak untuk membaca kalimat dengan alasan susah dan panjang".

Catatan Lapangan 8. Siswa H bisa mengeja akan tetapi belum bisa menggabungkan suku kata depan dan terakhir yang telah ia eja. Siswa $\mathrm{H}$ terkadang mengingat suku kata depan atau belakangnya saja sehingga ketika diminta menggabungkan ejaan ia 
asal menyebutkan kata. Terkadang guru membantu siswa $\mathrm{H}$ untuk menyebutkan kata yang tepat sesuai bacaan dengan menyebutkan salah satu suku kata. Misalnya, siswa H hanya mengingat kata "da" lalu guru menyebutkan kata "si". Kemudian, siswa H akan menyebutkan kata "dasi". Begitu juga ketika membaca frasa, guru selalu membantu siswa $\mathrm{H}$ untuk menyebutkan kata dan membaca frasa dengan tepat. Sementara itu, ketika membaca kalimat siswa $\mathrm{H}$ tidak mampu membacanya karena selalu lupa kata yang ada di awal kalimat.

Catatan Lapangan 9. Siswa I membutuhkan waktu yang cukup lama untuk mengeja kata. Apabila siswa I tidak mampu mengeja, ia akan melafalkan kata berdasarkan tebakannya. Kata-kata yang tidak mampu dieja siswa I berupa kata yang terdiri dari tiga suku kata dengan huruf tertutup. Siswa I juga melakukan hal sama ketika membaca frasa. Siswa I hanya bisa membaca satu kata dalam frasa dan kalimat. Siswa I tidak membaca frasa dengan kalimat secara tuntas.

Selain catatan lapangan tentang kesulitan membaca yang dialami siswa, peneliti juga melakukan wawancara pada guru kelas. Berikut ini merupakan transkrip wawancara peneliti dengan guru kelas terkait kesulitan membaca yang dialami siswa.

\section{Wawancara Guru A}

P:"Bagaimana pendapat Ibu tentang kesulitan membaca yang dialami siswa?"

G:"Kesulitan membaca sebenarnya wajar karena memang kelas satu baru diajar membaca. Tapi kan namanya juga anak jelas kemampuannya beda-beda. Jadi ada yang cepat bisa ada juga yang lamban".

P: "Jadi dapat dikatakan siswa yang sulit membaca itu termasuk lamban?"

G: "Bukan lamban dalam artian lamban belajar teh (panggilan pada perempuan dalam bahasa Sunda) tapi memang proses bisa membacanya tidak cepat. Soalnya kalo dibilang lamban belajar tidak juga karena mereka bisa mengikuti pelajaran lain. Bisa saja ketika di rumah mereka kurang banyak latihan membaca".

P: "Kesulitan apa saja yang dialami siswa kelas I dalam membaca Bu?"

G: "Biasanya siswa kelas I belum bisa mengeja, lupa kata yang sudah dia eja, membaca asal-asalan jadi kadang kata-katanya mereka menambahkan sendiri. Penambahan kata atau penggantian kata sangat sering dilakukan siswa yang sebenarnya sudah bisa membaca tetapi tidak bisa fokus".

P: "Bagaimana usaha Ibu untuk mengatasi kesulitan membaca siswa?"

G: "Kadang-kadang setiap pulang sekolah saya memberi jam tambahan pada siswa yang belum bisa membaca. Tapi bergilir, tidak sekaligus supaya fokus".

\section{Wawancara Guru B}

P:"Apa yang Ibu ketahui tentang kesulitan membaca?"

G:'Kesulitan membaca itu masalah yang dihadapi siswa terkait kemampuan membacanya. Kalau di kelas I kesulitan membaca itu wajar karena kan kelas I itu baru belajar membaca".

P:"Bagaimana cara Ibu mengetahui siswa yang mengalami kesulitan membaca?"

G:"Ketika saya meminta siswa untuk membaca bersama, biasanya siswa yang mengalami kesulitan hanya ikut melafalkan tapi tidak melihat tulisan. Kadang kan saya juga adakan tes membaca secara individual jadi saya tahu siswa yang belum bisa membaca".

P:'Kesulitan apa saja yang dialami siswa dalam membaca?"

G:"Ada yang belum bisa merangkai ejaan terus ada juga yang belum bisa mengeja sama sekali. Saya juga berusaha memberi jam tambahan sama siswa yang belum bisa membaca. Namanya juga siswa kelas I teh, kita tidak bisa memaksa mereka. Kadang ketika bersemangat mereka bisa mengikuti saya dan mampu mengeja. Tapi kalo sedang malas, jangankan mengeja teh menyebut nama huruf saja malas".

P:"Luar biasa ya Bu siswa kelas I".

G:"Itulah teh kebanyakan orangtua siswa hanya menitip anaknya pada kami. Terus inginnya mereka cepet bisa baca tapi orangtua kadang tidak tahu karakter anaknya sendiri. Ada yang mampu dengan tenang mengikuti, ada yang cepat hilang konsentrasi, ada juga yang seenaknya sendiri. Yang jelas saya sebagai guru sudah berusaha".

Berdasarkan hasil observasi dan wawancara maka dapat diketahui bahwa kesulitan membaca yang dialami siswa kelas I sekolah dasar sangat beragam. Hasil observasi menunjukkan kesulitan membaca yang dialami siswa kelas I sekolah dasar yaitu: (1) belum mampu membaca diftong, vokal rangkap, dan konsonan rangkap; (2) belum mampu 
membaca kalimat; (3) membaca tersendat-sendat; (4) belum mampu menyebutkan beberapa huruf konsonan; (5) belum bisa mengeja; (6) membaca asal-asalan; (7) cepat lupa kata yang telah diejanya; (8) melakukan penambahan dan penggantian kata; (9) mengeja dengan waktu yang cukup lama; (10) belum mampu membaca dengan tuntas.

Kesulitan membaca yang dialami siswa di Indonesia hampir serupa dengan kesulitan membaca dialami siswa di luar negeri. Salah satu contohnya yaitu kesulitan membaca yang dialami siswa kelas empat sekolah dasar di Ogong, Namibia. Hasil penelitian Mule (2014) menunjukkan beberapa jenis kesulitan membaca sebagai berikut: (a) siswa membaca kata secara terbalik seperti /on/menjadi /no/ atau /who/menjadi /how/; (b) siswa menghilangkan kata dalam kalimat, misalnya ada kalimat "semua anak mengambil balon dan membawanya ke dalam ruangan" menjadi "anak mengambil balon ke dalam ruangan"; (c) siswa mengubah makna kalimat, misalnya ada kalimat "Samson menendang batu" menjadi "Samson ditendang batu"; (d) siswa menambahkan kata dalam kalimat, misalnya ada kalimat "Samson duduk di tribun" menjadi "Samson duduk di atas tribun".

Kesulitan membaca yang dialami siswa sekolah dasar sesuai dengan pendapat Abdurrahman (2012) serta Bond, dkk (1994) yang meliputi: (1) vowel errrors, tidak dapat melafalkan beberapa huruf vokal dan tidak mampu membaca vokal rangkap; (2) consonant errors, tidak mampu membaca diftong serta beberapa huruf konsonan; (3) tidak mampu membaca huruf gabungan; (4) penambahan huruf, misal bau menjadi batu; (5) penghilangan huruf, misal tuan menjadi tua; (6) penambahan kata, misal "suatu hari ada seorang Raja" menjadi "suatu hari ada seorang Putri Raja"; (7) penghilangan kata, misal "tidak ada ibu" menjadi "ada ibu"; (8) tidak mampu mengidentifikasi huruf atau mengeja lebih dari 15 detik (lamban membaca); (i) membaca tersendatsendat.Hasil ini selaras dengan beberapa penelitian yang sudah dilaksanakan secara terdahulu.

Kesulitan membaca biasanya dianggap hanya terjadi pada siswa yang memiliki kelainan seperti disleksia atau $A D H D$ padahal banyak ditemukan kasus-kasus kesulitan membaca yang dialami siswa tanpa riwayat kelainan apapun. Hal ini sejalan dengan pendapat Slavin, dkk (2014) yang menyatakan bahwa siswa yang kurang lancar mengeja dan membaca dapat dikatakan memiliki kesulitan membaca tetapi guru-guru tidak menyadari hal tersebut dan menganggap mereka akan lancar membaca jika naik kelas berikutnya.

Liu, dkk (2008) menyatakan bahwa kesulitan membaca pada anak terbagi ke dalam dua jenis yaitu kesulitan membaca dikarenakan suatu kelainan genetika dan kesulitan membaca dikarenakan rendahnya kemampuan membaca siswa (poor reading). Kesulitan membaca yang disebabkan kelainan genetika biasanya terjadi pada anak penderita disleksia sedangkan poor reading terjadi pada anak yang mempunyai kemampuan membaca lebih rendah dari kemampuan membaca normal (Gillet, dkk, 2012).

Dalam kaitannya dengan kegiatan pembelajaran di sekolah kesalahan-kesalahan yang sering dilakukansiswa ketika membaca dapat dikategorikan sebagai kesulitan membaca Zubaidah (2013). Siswa yang mengalami kesulitan membaca memiliki kemampuan membaca lebih lamban daripada siswa yang tidak mengalami kesulitan membaca Nathan (2006). Oleh sebab itu, perlu adanya tindakan untuk menganalisis kesulitan membaca yang dialami siswa. Kesulitan menbaca yang dialami siswa SD menurut hasil penelitian Basuki (2011) dikaitkan dengan pola pembelajaran yang dilakukan guru. Dinyatakan bahwa pola pembelajaran membaca yang dilakukan guru cenderung bersifat statis dan klasik. Semua aktivitas dilakukan tanpa adanya upaya untuk meningkatkan kemampuan membaca. Siswa cenderung membaca dengan caranya sendiri.

Analisis kesulitan membaca sangat penting dilakukan guru maupun orangtua untuk mengenali kesulitan yang dimiliki siswa sehingga mereka dapat diberi penanganan secara tepat (Slavin, dkk, 2014). Analisis kesulitan membaca telah dilakukan Mule (2014) di Ogong, Namibia. Mule (2014) melakukan penelitian untuk menemukan jenis kesulitan membaca dan penyebabnya dalam bahasa Inggris di kelas 4 sekolah dasar. Mule (2014) menemukan beberapa jenis kesulitan membaca sebagai berikut (a) siswa membaca kata secara terbalik seperti /on/ menjadi /no/ atau /who/ menjadi /how/; (b) siswa menghilangkan kata dalam kalimat, misalnya ada kalimat "semua anak mengambil balon dan membawanya ke dalam ruangan" menjadi "anak mengambil balon ke dalam ruangan"; (c) siswa mengubah makna kalimat, misalnya ada kalimat "Samson menendang 
batu" menjadi "Samson ditendang batu"; (d) siswa menambahkan kata dalam kalimat, misalnya ada kalimat "Samson duduk di tribun" menjadi "Samson duduk di atas tribun". Upaya peningkatan kemampuan membaca dilakukan pada penelitian Muslich (2010) yang hasilnya peningkatan kemampuan membaca permulaan siswa kelas I dengan metode Mueller ini dilakukan guru dengan menggabungkan beberapa aktivitas dalam metode Mueller. Untuk memudahkan siswa, guru menggunakan tulisan dan ejaan.

Analisis kesulitan membaca dalam bahasa Inggris juga dilakukan oleh Hartney (2011) di kelas 3 sekolah dasar Namibia. Hartney (2011) menemukan beberapa kesulitan membaca bahasa Inggris di kelas 3 sekolah dasar di antaranya (a) siswa tidak mampu membunyikan huruf dengan tepat, ketika guru menulis huruf $/ \mathrm{b} /$ mereka bukan membunyikan /bi/ tetapi /ha/ atau /ka/; (b) siswa tidak mampu membaca dua vokal yang bersisian seperti /ee/ atau / ea/; (c) siswa tidak mampu membaca kalimat secara tuntas; (d) dan siswa memiliki kecepatan membaca yang lamban atau berada pada tingkat frustrasi.

\section{SIMPULAN DAN SARAN}

\section{Simpulan}

Kesulitan membaca adalah suatu keadaan ketika siswa tidak mampu mengidentifikasi kata sehingga siswa memiliki kemampuan membaca rendah berdasarkan rerata kemampuan membaca yang telah ditetapkan. Kesulitan membaca perlu dilakukan agar guru dapat mengidentifikasi kesulitan yang dialami siswa sehingga dapat memberi tindak lanjut yang tepat.

Berdasarkan hasil observasi dan wawancara yang telah dilakukan maka dapat disimpulkan bahwa kesulitan siswa kelas I sekolah dasar dalam membaca permulaan yaitu: (1) belum mampu membaca diftong, vokal rangkap, dan konsonan rangkap; (2) belum mampu membaca kalimat; (3) membaca tersendat-sendat; (4) belum mampu menyebutkan beberapa huruf konsonan; (5) belum bisa mengeja; (6) membaca asal-asalan; (7) cepat lupa kata yang telah diejanya; (8) melakukan penambahan dan penggantian kata; (9) mengeja dengan waktu yang cukup lama; (10) belum mampu membaca dengan tuntas.

\section{Saran}

Berdasarkan hasil penelitian yang telah diuraikan peneliti memberi saran agar guru memberi sosialisasi pada orangtua siswa tentang kesulitan membaca yang dialami siswa. Kesulitan membaca bukan hanya tanggung jawab guru tetapi tanggung jawab bersama sehingga akan lebih jika diatasi bersama. Siswa yang mengalami kesulitan membaca perlu diberi perlakuan lebih di rumah dan di sekolah. Guru dapat memberi waktu tambahan untuk mengajarkan siswa membaca. Kemudian guru memberi buku penghubung dan menulis hal-hal yang perlu diajarkan orangtua di rumah sehingga terjalin sinergi antara guru dan orangtua siswa. Siswa yang mengalami kesulitan membaca sebaiknya mendapat penilaian berbeda dengan siswa lain. Penilaian bagi siswa yang mengalami kesulitan membaca diukur berdasarkan kemampuan membaca siswa tersebut. Sebagai contoh, siswa yang belum bisa mengeja sama sekali diberi kartu bergambar untuk ditebak siswa.

\section{DAFTAR RUJUKAN}

Abdurrahman, M. 2012. Anak Berkesulitan Belajar: Teori, Diagnosis, dan Remediasinya. Jakarta: Rineka Cipta.

Abidin, Y. 2010. Strategi Membaca Teori dan Pembelajarannya. Bandung: Rizqi Press.

Basuki, A.I. 2011. Profil Pembelajaran Membaca Pemahaman di Sekolah Dasar. Jurnal Sekolah Dasar Th.20 No.2 Nov 2011, hal 77-85. Malang: Prodi PGSD FIP UM.

Bond, G.L. 1994. Reading Difficulties Their Diagnosis and Correction. Needham Heights: Allyn and Bacon.

Cohen, L., Manion, L., \& Marrison, K. 2007. Research in Education Sixth Edition. Newyork: Routledge. Contemporary View. Journal of Research in Special Educational Needs, 13, 7-14.

Creswell, J. W. 2014. Penelitian Kualitatif dan Desain Riset. Yogyakarta: Pustaka Pelajar.

Creswell, J. W. 2015. Riset Pendidikan: Perencanaan, Pelaksanaan, dan Evaluasi Riset Kualitatif \& Kuantitatif. Yogyakarta: Pustaka Pelajar.

Curtain, H., Donato, R., \& Gilbert, V. 2016. Elementary School Foreign Language 
Programs in the United States. In Foreign Language Education in America (pp.19-41). Palgrave Macmillan UK.

Dalman. 2014. Keterampilan Membaca. Jakarta: Raja Grafindo Persada.

Denzin, N.K. \& Lincoln, Y.S. 2009. Handbook of Qualitative Research. Yogyakarta: Pustaka Pelajar.

Gillet, J.W. 2012. Understanding Reading Problems Assesment and Instruction Eight Edition. Boston: Pearson.

Granger, L. A. 2016. Encouraging the Use and Activation of Heritage Languages in the Broader Educational System. In Handbook of Research and Practice in Heritage Language Education (pp.1-21). Springer International Publishing.

Hartney, R.N. 2011. Investigating Reading Difficulties in English Second Language of Grade 3 Learners in One Primary School in the Khomas Education Region of Namibia. (Online) (http://wwwisis.unam.na/theses/ hartney2011.pdf ) diakses 12 Januari 2017.

Liu, Y.J. 2008. From Early Childhood Special Education to Special Education Resources Room Identification, Assessment, and Eligibility Determinations for English Language Learners with Reading Related Disabilities. Assessment for Effective Intervention, 33(3):177-187.

Lyon, G., Shaywitz, S. E., \& Shaywitz, B. A. 2003. A Definition of Dyslexia. Annals of Dyslexia, 53(1):1-14.

Margono, S. 2014. Metode Penelitian Pendidikan. Jakarta: Rineka Cipta.

Mule, K. 2014. Types and Cause of Reading Difficulties Affecting the Reading of English Language: a Caseof 4 Grade Learners in Selected Schools in Ogong Circuit of Namibia. (Online). (http://uninam.na/theses/mule2014. pdf) diakses 2 Februari 2017.

Muslich, M. 2010. Upaya Peningkatan Kemampuan Membaca Permulaan Siswa Kelas I SD dengan Metode Mueller. Jurnal Sekolah Dasar Th.19 No.1: hal 81-90. Malang: Prodi PGSD FIP UM.
Nathan, K. 2006. Reading Difficulties and Social Problems. (Online) (http://www.ir.canterbury. ac.nz/bitstream/handle/10092/1339/thesis fulltext.pdf) diakses 21 Januari 2017.

Petersen, D.B., Alen, M., \& Spencer, T.D. 2016. Predicting Reading Difficulty in First Grade Using Dynamic Assesment of Decoding in Early Kindergarten: A Large-Scale Longitudinal Study. Journal of Learning Disabilities, 49(2):200-215.

Rahim, F. 2008. Pengajaran Membaca di Sekolah Dasar. Jakarta: Bumi Aksara.

Schleppegrell, M. J. 2016. Content-based language teaching with functional grammar in the elementary school. Language Teaching, 49(1):116-128.

Silverman, R. D., Martin-Beltran, M., Peercy, M. M., Hartranft, A. M., McNeish, D. M., Artzi, L., \& Nunn, S. 2017. Effects of a Cross-Age Peer Learning Program on the Vocabulary and Comprehension of English Learners and NonEnglish Learners in Elementary School. The Elementary School Journal, 117(3), 000-000.

Slavin, E.R. 2014. Membaca Membuka Pintu Dunia Program Success for All Model yang Jelas dan Kuat untuk Meningkatkan Kemampuan Membaca Anak Sekolah Dasar. Edisi kedua. Yogyakarta: Pustaka Pelajar.

Snowling, M. J. 2013. Early Identification and Interventions for Dyslexia: A

Suharsaputra, U. 2014. Metode Penelitian Kuantitatif, Kualitatif, dan Tindakan. Bandung: Refika Aditama.

Tarigan, H.G. 2008. Membaca sebagai Suatu Keterampilan Berbahasa. Bandung: Angkasa.

Zubaidah, E. 2013. Kesulitan Membaca Permulaan pada Anak Diagnosa dan Cara Mengatasinya. Yogyakarta: Universitas Negeri Yogyakarta. 